\title{
Europejskie przywództwo. Niemcy w Unii Europejskiej
}

W 1990 roku jeden ze znanych niemieckich badaczy August Pradetto przygotował analizę skutków niemieckiej jedności i przyszłości integracji europejskiej (Pradetto, 1990, s. 45-64). Pomimo upływu czasu, tezy Pradetto nie straciły na aktualności. Jest to ważna uwaga, bo literatura naukowa podlega tym samym procesom co ludzie; starzeje się, traci na wartości, a w wielu przypadkach już po kilku latach staje się zwykłą makulaturą. Pozbawioną wartości i znaczenia. To co było ważne jeszcze wczoraj, przestaje być aktualne dzisiaj. Zmieniają się bowiem priorytety, uwarunkowania i zależności. Nie da się tego powiedzieć o analizie Pradetto.

Swoje rozważania Pradetto rozpoczął od stwierdzenia, że era powojenna wyznaczona przez konflikty i konsekwencje II wojny światowej dobiegła końca (Pradetto, 1990, s. 45). Linia podziału dzieląca kontynent, przynajmniej teoretycznie, zniknęła. Europa stała się - jak naiwnie zakładano - jednością. W takim też kontekście Pradetto pisał o wzajemnym stosunku integracji i dezintegracji europejskiej, o wzajemnych relacjach internacjonalizmu i nacjonalizmu. Stawiał zasadnicze pytania o przyszłość zjednoczonej Europy. Podstawowe jednak pytanie brzmiało jaki charakter będzie miała owa oczekiwana przez wszystkich europejska jedność? Jaką rolę w tym procesie będą odgrywały zjednoczone Niemcy? Pradetto już wówczas otwarcie wyrażał swoje wątpliwości czy 80-milionowe Niemcy, obiektywnie najsilniejsze europejskie mocarstwo przemysłowe uda się w ogóle zintegrować $\mathrm{z}$ ogólnoeuropejską strukturą bezpieczeństwa?

Według niemieckiego badacza, pomimo tylu tragicznych doświadczeń historycznych, władza, panowanie, ideologia, systemy polityczne rządzą się własnymi regułami i prawami; mają swoją wewnętrzną dynamikę (Pradetto, 1990, s. 50). Ich sterowalność jest więcej niż ograniczona i zależy od wielu czynników. Pradetto wyrażał też pogląd, że mechanizm atrakcji (przyciagania) i polityki wpływów potężnych krajów i ruchów rozwija się sam i to niemal automatycznie: często bez jakiejkolwiek złej woli (Pradetto, 1990, s. 48). Już wtedy niemiecki badacz zakładał, że przyszła europejska jedność będzie się rozwijała według niemieckiego modelu. Wymieniał m.in. przykłady Polski i Wegier jako krajów rywalizujących ze sobą w dostępie do niemieckiego kapitału i związanych z tym konfliktów i nieporozumień. Kluczem w całej analizie Pradetto jest jego uwaga, że europejski pociąg będzie w przyszłości prowadzony przez Niemcy, a inni będą musieli się do niego dopasować i dostosować (Pradetto, 1990, s. 50).

Analizę Pradetto wyróżnia przede wszystkim jej rzeczowość, obiektywizm i dalekowzroczność. W odniesieniu do Polski proroczo pisał, że łatwo sobie wyobrazić ten kraj jako biednego i chorego człowieka Europy; źle zarządzanego, słabego politycznie i gospodarczo. Stawiał hipotetyczne pytanie czy np. Śląsk nie będzie chciał w przyszłości odłączyć się od Polski i zjednoczyć z Niemcami? Pytanie Pradetto było rozmyśl- 
nie prowokacyjne, ale badacz od razu przypominal, że niemiecka gotowość ,,pomocy” na Pomorzu i Śląsku jest widoczna i znamienna.

W opracowaniu Helmuta Hubla i Bernharda Maya z Instytutu Badawczego Niemieckiego Towarzystwa Polityki Zagranicznej z 1995 roku znajdujemy jednoznaczną deklarację byłego kanclerza RFN Helmuta Kohla (Hubel, May, 1995). Czytamy w niej m.in., że: „zjednoczone Niemcy są, o czym nasi sąsiedzi wiedzą, numerem jeden w Europie. Mamy 80 milionów mieszkańców. Jesteśmy krajem o najsilniejszej gospodarce w Europie. Jesteśmy też szczególnie dobrze zorganizowani, co w nowoczesnych społeczeństwach przemysłowych ma wielkie znaczenie. Inni zgadzają się z nami naturalnie, że potrzebujemy największego mieszkania" (Hubel, May, 1995, s. 1). Zwłaszcza ostatnia uwaga byłego niemieckiego kanclerza brzmiała niepokojąco i dwuznacznie. Przypominała bowiem o koncepcji Lebensraumu - przestrzeni życiowej dla narodu niemieckiego i drugiej wojnie światowej.

W swoich analizach badacze niemieccy stawiali tak podstawowe pytanie jak to, czy Niemcy w związku ze swoją przeszłością w ogóle mogą być normalnym krajem. Jeden z najbardziej znanych badaczy brytyjskich zajmujących się tematyką niemiecką Timothy Garton Ash pisał, że zjednoczone Niemcy czy tego chcą, czy nie chcą stały się znowu mocarstwem przywódczym w podzielonej gospodarczo i politycznie Europie (Ash, 1993, s. 521). Z badaczy polskich oceniających rzeczywiste relacje pomiędzy Unią Europejska, a Niemcami najostrzejsze tezy formułował Adam Schaff; zmarły wybitny badacz i filozof stwierdzał wprost, że Unia Europejska jest niemiecką Unią a RFN kontynuuje politykę Bismarcka (Schaff, 1999, s. 228). Schaff najbardziej obawiał się niemieckiej polityki faktów dokonanych po przyjęciu Polski do UE; reprezentowal m.in. pogląd, że wbrew oficjalnym deklaracjom Niemcy nie zrezygnowaly ze swoich byłych obszarów wschodnich (tzw. ziemie odzyskane w Polsce) i że rozszerzenie Unii na Wschód tylko ułatwi niemiecką ekspansję (Schaff, 1999, s. 241). Z dzisiejszej perspektywy obawy Schaffa moga się wydawać przesadne lub przynajmniej przedwczesne. Nie da się ich jednak ignorować, zwłaszcza w kontekście niemieckiego potencjału i wiodącej roli odgrywanej przez Niemcy w UE.

W 2006 roku jeden z polskich badaczy zajmujących się kwestią niemiecką postawił 2 zasadnicze tezy:

1) polityka zagraniczna Konrada Adenauera miała swoje czasowe ograniczenie i mogła obowiązywać tylko do zjednoczenia Niemiec. Przywrócenie niemieckiego państwa narodowego zmieniło priorytety niemieckiej polityki zagranicznej;

2) od czasów Gerharda Schrödera Niemcy kontynuują tradycyjną politykę zagraniczną ograniczoną przez członkostwo w UE i NATO i przyjęły strategię zmiennych politycznych sojuszy oraz suwerennego wyboru partnerów w stosunkach międzynarodowych (Młynarski, 2006, s. 9).

Ten sam autor stwierdzał dalej, że ograniczony charakter integracji zachodnio-europejskiej Konrada Adenauera, podział Niemiec na dwa państwa, bipolarny układ świata skutecznie równoważyły dwa potencjały: niemiecki i europejski. Zjednoczenie Niemiec radykalnie zmieniło te proporcje i stosunek sił w Europie. Niemcy po raz kolejny stały się najsilniejszym mocarstwem Europy (Młynarski, 2006, s. 255). Swoje wątpliwości co do prawdziwego charakteru i przyszłości całej Unii Europejskiej oraz roli Niemiec wyrażał również znany amerykański politolog George Friedman (Friedman, 
2012). Zwrócił on między innymi uwagę, że pierwsza fala światowego kryzysu gospodarczego z 2008 roku najsilniej dotknęła Europę Wschodnią. System bankowy krajów tego obszaru został wykupiony przez banki niemieckie, austriackie, francuskie, szwedzkie i włoskie. W Republice Czeskiej system bankowy został przejęty przez obcy kapitał w 96\% (Friedman, 2012, s. 188).

Według Friedmana najsilniejsi członkowie UE tacy jak Niemcy w okresie kryzysu zwiększyli swoją gospodarczą i polityczną suwerenność, natomiast słabsze kraje częściowo ją utraciły (Friedman, 2012, s. 189). Amerykański badacz zwracał też uwage, że jeśli nawet Unia Europejska się nie rozpadnie, to została ona pomyślana najpierw jako strefa wolnego handlu i tylko jako taka strefa przetrwa ewentualnie w przyszłości (Friedman, 2012, s. 181). Friedman dostrzegł również, że w czasie kryzysu greckiego (czy też greckiej tragedii jak to określają zachodni badacze) większość Niemców sprzeciwiła się udzielaniu jakiejkolwiek pomocy finansowej Grecji. To ważna uwaga w kontekście interpretacji roli i zamiarów Niemiec w Unii Europejskiej. Dalej Friedman stwierdzał, że większość Greków wolała bankructwo niż podporządkowanie się warunkom narzuconym przez Unię, gdyż postrzegali je jako niemiecki dyktat (Friedman, 2012, s. 191). Właśnie owa grecka katastrofa dostarczyła wielu argumentów zwolennikom tezy o zauważalnej renacjonalizacji niemieckiej polityki zagranicznej i powrotu do polityki państwa narodowego z własnymi interesami i priorytetami. Powrotu do polityki Bismarcka. W analizie europejskiego przywództwa prawdziwym kluczem do jego interpretacji jest uwaga Friedmana, że kraj, który nie kontroluje własnego systemu finansowego czy waluty, jest bardzo podatny na działania innych krajów (Friedman, 2012, s. 72). Traci swoją gospodarcza niezależność i suwerenność. W pewnym sensie taki kraj jest kolonizowany i kontrolowany przez najsilniejszych. Uwagi Friedmana staną się punktem wyjścia w formułowanych dalej wnioskach.

Niemiecki badacz Stephan Kaufmann w analizie pod znamiennym tytułem Europa unter deutscher Fuchtel - Europa w niemieckich karbach (Kaufmann, 2012, s. 5-8) ostro krytykował europejską politykę Angeli Merkel. Jako drastyczny przykład jej skutków Kaufmann opisywał zachowanie irlandzkiego rządu z jesieni 2011 roku. Rząd irlandzki debatował nad zwiększeniem wpływów finansowych państwa, by w przyszłości obniżyć jego zadłużenie. Planowano m.in. podwyższenie dotychczasowej stawki VAT i sprzedaż niektórych przedsiębiorstw państwowych. Jednak zanim rząd irlandzki przedłożył odpowiedni projekt ustawy własnemu parlamentowi, został on wcześniej przesłany dla uzyskania aprobaty niemieckiemu Bundestagowi (Kaufmann, 2012, s. 5). Opozycja nazwała ten krok bezprzykładnym złamaniem zaufania (beispiellose Vertrauensbruch), a w Dublinie doszło do prawdziwego skandalu. W opinii Kaufmanna tylko ten epizod pokazywał najlepiej jakiej Europy życzy sobie w przyszłości rząd federalny (Kaufmann, 2012, s. 5). Niemiecki badacz nie bawił się w dyplomację i ostro stwierdzał, że rząd federalny uczynił znaczący krok do przodu w kierunku kontroli całej Europy (Kaufmann, 2012, s. 5).

Na przykładzie Grecji Kaufmann udowadniał podwójną moralność w polityce gospodarczej Berlina; w Grecji w roku 2011 pomimo drastycznych ograniczeń w wydatkach i podwyższeniu podatków ogromny deficyt państwa nie zmniejszył się. Z zasadniczego powodu: w czasach kryzysu rząd reaguje zwiększeniem wydatków tak jak zrobiły to Niemcy w 2009 i 2010 roku, a dopiero po przywróceniu koniunktury decyduje się na 
oszczędności. W tym jednak konkretnym przypadku Grecja nie uzyskała ani takiej szansy, ani takiej zgody. Zdaniem Kaufmanna w rezultacie takiej krótkowzrocznej i egoistycznej polityki deficyt budżetowy Grecji zwiększył się jeszcze bardziej. Według Kaufmanna Unia Europejska nie podjęła żadnych decyzji o zwiększeniu wzrostu gospodarczego Grecji, co jeszcze bardziej podważało jej wiarygodność (Kaufmann, 2012, s. 6). W praktyce jedyną strategią była wyłącznie polityka drastycznego oszczędzania $\mathrm{i}$ to $\mathrm{w}$ nieograniczonym czasie.

Polityka Angeli Merkel - zdaniem Kaufmanna - koncentrowała się tylko na środkach służących podniesieniu międzynarodowej konkurencyjności (Kaufmann, 2012, s. 6). Taka polityka była wzorowana na niemieckiej, stanowiła jej odbicie (Agenda 2010) i chodziło w niej o obniżenie kosztów pracy, obniżenie kosztów produkcji i zwiększenie eksportu. Ekonomiczne mechanizmy, które służyły tak silnej gospodarce jak niemiecka, równocześnie dusiły i dławiły gospodarki słabsze takie jak grecka. Na gruncie polskim Julian Bartosz oceniał, że Angela Merkel nazywana Frau Europa najpierw chce rozszerzyć i pogłębić kontrolę Brukseli, w której tylko teoretycznie i pozornie Niemcy mają równy głos z innymi; faktycznie brzmi on najmocniej i de facto jest w stanie kontrolować budżety narodowe innych krajów. Narzucać własne warunki i kryteria. Cytowana przez Bartosza profesor Ulrike Guerot z Europejskiej Rady Spraw Zagranicznych przyznawała, że rola Niemiec w Europie jest dwuznaczna (Bartosz, 2013, s. 46).

W debacie z 6 kwietnia 2011 roku w Europejskiej Radzie Stosunków Międzynarodowych (European Council on Foreign Relations) również zajęto się relacjami pomiędzy Europą a - jak to ujęto - nową kwestią niemiecką (Joschka, Enderlein, 2011, s. 45-63). Dyskusja odbywała się pod znamiennym tytułem Europa i ponowne odkrycie niemieckiego państwa narodowego. Uwagę zwracał skład jej uczestników: Jürgen Habermas, Joschka Fischer, Henryk Enderlein i Christian Calliess. Habermas jest uważany za jednego z najwybitniejszych współczesnych filozofów, Joschka Fischer to były minister spraw zagranicznych RFN, dwaj pozostali uczestnicy tej debaty to renomowani niemieccy politologowie.

Joschka Fischer zgodził się z Ulrike Guerot, że współcześnie obserwujemy renacjonalizację niemieckiej polityki zagranicznej dokonującą się na niekorzyść Europy (Joschka, Enderlein, 2011, s. 45). Fischer starał się usprawiedliwiać tą widoczną zmianę dotychczasowych priorytetów tej polityki; jego zdaniem nie była ona wyrazem świadomych decyzji w znaczeniu strategicznej zmiany, ale była nieuchronną konsekwencją przemian, które nastapiły po zjednoczeniu Niemiec. Równocześnie jednak ten sam Fischer przyznawał, że bynajmniej nie poprawia to obrazu i wymowy owej zmiany. W dalszych uwagach Fischer nie ukrywał, że beneficjentem numer jeden wprowadzonego euro jako wspólnej waluty są przede wszystkim Niemcy. Za wielką europejską trójkę uznał Niemcy, Francję i W. Brytanię. Decydującą o przyszłości i charakterze Unii Europejskiej.

Według Fischera bez autentycznej jedności tych trzech europejskich mocarstw nie może być mowy o żadnej wspólnej europejskiej polityce obronnej i zagranicznej (Jochka, Enderlein, 2011, s. 47). Zgodził się, że Europa znajduje się w fatalnym stanie i że to jeszcze bardziej podkreśla wielką rolę, jaką na kontynencie odgrywają zjednoczone Niemcy. W takim kontekście odwołał się do słynnej pracy Karola Marksa 18 Brumaire 'a 
i sparafrazował jego myśl, że to co dzisiaj jest uznawane tylko za farse, w XIX i XX stuleciu stało się prawdziwą tragedią (Joschka, Enderlein, 2011, s. 47). Było to jasne i niedwuznaczne nawiązanie Fischera do sytuacji, w której znalazła się Unia Europejska na przełomie XX i XXI stulecia.

Odnosząc się już bezpośrednio do nowej i tak niepokojącej wielu obserwatorów roli Niemiec w Europie Fischer przyznawał, że to poczucie własnej siły i przekonanie o słabości innych jest niebezpieczną tendencją, która jednak niekoniecznie musi doprowadzić do nowej europejskiej tragedii (Joschka, Enderlein 2011, s. 47). Ta ostatnia uwaga Fischera miała wyraźnie warunkowy charakter i jej celem było uspokojenie ewentualnych obaw obserwatorów niemieckiej polityki zagranicznej co do możliwej nowej hegemonii Niemiec w Europie. Uznał również, że brak zainteresowania ze strony niektórych krajów europejskich kontynuacją integracji europejskiej może się przełożyć na powrót do fatalnej polityki znanej z przeszłości. Polityki egoistycznego interesu narodowego i podejmowania prób relatywizacji historii lub instrumentalnego zapominania o przeszłości. Stwierdzał wręcz, że jeśli proces renacjonalizacji niemieckiej polityki zagranicznej jeszcze bardziej się pogłębi, to cały projekt europejski stanie pod wielkim znakiem zapytania (Joschka, Enderlein, 2011, s. 48). Przypomniał też o greckiej tragedii (kryzys gospodarczy, społeczny i polityczny w tym kraju) i szczególnej odpowiedzialności UE, a zwłaszcza Niemiec za taki stan rzeczy.

Fischer poddał wyjątkowo ostrej krytyce konstrukcyjne błędy Unii Europejskiej. Jego zdaniem uprawnienia Parlamentu Europejskiego wobec narodowego suwerena były niewielkie i nie pozwalały na wprowadzenie jakichkolwiek koniecznych zmian i korekt. W sprawach wewnątrzniemieckich byly minister spraw zagranicznych tego kraju dał wyraz swojemu wielkiemu niepokojowi; wśród młodej generacji członków Bundestagu nie dostrzegał nikogo, kto byłby gotowy dalej rozwijać wizję zjednoczonej Europy, angażować się intelektualnie czy ryzykować swoją polityczną przyszłość (Joschka, Enderlein, 2011, s. 48). Fischer ujął to obrazowo i otwarcie stwierdzał, że z Europy jak z balonu uchodziło powietrze. Z kolei moderująca dyskusję Ulrike Guerot przypomniała radykalną tezę brytyjskiego historyka Nialla Fergusona, że jesteśmy świadkami powolnej implozji Europy.

Henrik Enderlein zauważył, że unia walutowa została pomyślana jako projekt polityczny, a nie ekonomiczny. W okresie jej tworzenia każdy ekonomista doskonale wiedzial, że jeśli nie zostanie ona wprowadzona na obszarze, który nie jest optymalny, ponieważ nie jest homogeniczny, jeśli więc kraje członkowskie zarówno te silne, jak $i$ te słabe będą uprawiały tą samą politykę finansowa, to nieuchronnie powstanie ekonomiczna nierównowaga, która dla krajów słabszych gospodarczo skończy się autentyczną katastrofą. W takim rozwiązaniu Enderlein upatrywał też fatalnego grzechu pierworodnego Unii Europejskiej, który w bliższej lub dalszej perspektywie mógł doprowadzić do jej rozpadu.

Te same kryteria ekonomiczne dla krajów gospodarczo silnych i słabych musiały doprowadzić do europejskiego kryzysu. Trwałego podziału na kraje bogate i biedne. Na północ i południe. Układ z Maastricht naiwnie zakładał, że wspólna waluta zwiększy dobrobyt wszystkich. Będzie uniwersalnym środkiem wzrostu gospodarczego. Tymczasem powstała sytuacja dokładnie odwrotna. Silne europejskie gospodarki dzięki euro jeszcze bardziej umocniły swoją pozycję, słabe pogrążyły się w dramatycznym 
kryzysie. Z naturalnych powodów nie były i nie są one w stanie konkurować z Niemcami czy Francją. W debacie skupiono się również na kwestii takiej, a nie innej konstrukcji Unii Europejskiej i wiążących się z tym ostrych kontrowersji i różnych interpretacji.

Christian Calliess definiował UE jako federalny związek, rodzaj federacji państw. Od razu jednak zaznaczał, że za pomocą tradycyjnych pojęć ze słownika prawa międzynarodowego praktycznie nie da się ująć jej istoty (Joschka, Enderlein, 2011, s. 53). Jego zdaniem katastrofalny wpływ na dalszy rozwój UE miało zmęczenie obywateli Europa; nawet $w$ europeistyce jako nauce dały się zaobserwować przejawy intelektualnej bezradności i wyczerpania (Joschka, Enderlein, 2011, s. 56). Zwrócił uwagę na niebezpieczeństwo wygrywania przeciwko sobie wzajemnych relacji pomiędzy kwestią demokracji a konstrukcją UE. Istniejący głęboki konflikt idei pogłębienia i równoczesnego rozszerzenia UE to według Calliessa problem, którego nikt nie był i nie jest w stanie rozwiązać. Calliess zwrócił również uwagę na fundamentalną kwestię europejskiego przywództwa. Kto jest prawdziwym hegemonem w Europie? Kto właściwie i w jaki sposób decyduje o najważniejszych europejskich sprawach? Takie były najważniejsze pytania stawiane w tej dyskusji, w której stale podkreślano nierównowage, kontrowersyjność i niejednoznaczność całego procesu integracji europejskiej.

Według Jürgena Habermasa Europa dziedziczyła spuściznę średniowiecznych imperiów i państw narodowych. W warunkach europejskiego kryzysu oczekiwany pluralizm idei i postaw załamywał się i zwiększał rolę najsilniejszych europejskich państw. To one przejmowały rolę przywódczą. W polemice z Habermasem Joschka Fischer otwarcie stwierdzał, że współczesne stosunki pomiędzy Francją a Niemcami określa $\mathrm{w}$ istocie niszczący potencjał wzajemnych sporów i pretensji; $\mathrm{w}$ takim też kontekście Fischer zaznaczal, że sytuacja, w której Niemcy i Francja znowu stają naprzeciwko siebie prowadzi do paraliżu całej Unii Europejskiej (Joschka, Enderlein, 2011, s. 60). Andre Wilkens z fundacji Mercator w swoich wnioskach poszedł jeszcze dalej - jego zdaniem - jeśli Niemcy stają się coraz silniejsze i swoją siłę wykorzystują, to mamy do czynienia z nową odsłoną kwestii niemieckiej w Europie (Joschka, Enderlein, 2011, s. 61). Z tezą Wilkensa polemizował Jürgen Habermas. Habermas uważał, że Niemcy w klasycznym sensie nie narzucają swoich mocarstwowych interesów innym krajom europejskim. Była to teza badawczo sporna i łatwa do obalenia, zwłaszcza w kontekście polityki zagranicznej RFN wobec Jugosławii w latach 1991-1999.

Thilo Bode jako jeden z badaczy niemieckich zajmujących się źródłami kryzysu greckiego uznał, że Grecja jest krajem znajdującym się w stanie permanentnego stanu wyjątkowego (Bode, 2013, s. 39). Bode pisał, że praktycznie w Grecji nie ma już czegoś takiego jak normalne życie. Następował - jego zdaniem - społeczny i ekonomiczny rozpad Grecji oraz widoczna na każdym kroku pauperyzacja ludności. Co drugi młody człowiek w tym kraju nie miał żadnej pracy, zwielokrotniła się liczba samobójstw, rosła też przemoc ze strony kryminalnych band i gangów. Niemiecki badacz zwracał uwagę, że na terenie Grecji coraz większą popularnością cieszą się partie skrajnie prawicowe, neofaszystowskie takie jak „Zloty Świt”. Wedhug Bode w Grecji rósł też strach dużej czę́ci społeczeństwa przed społecznymi warunkami z okresu schyłkowej Republiki Weimarskiej (Bode, 2013, s. 39). Bode pisał, że wysokie bezrobocie i dramatyczny grecki kryzys gospodarczy stanowiły nieuchronny rezultat polityki ratowania za wszelką cenę euro $\mathrm{w}$ tym kraju. Bode reprezentował pogląd, że powrót do 
drachmy w znaczącym stopniu obniżyłby poziom bezrobocia na terenie Grecji. Umożliwiłby kontrolę narodowej waluty, jej dewaluację i zapewnił konkurencyjność greckich towarów. Pod naciskiem Unii Europejskiej, a zwłaszcza Niemiec greckie partie polityczne obawiały się podjąć takie ryzyko. Najważniejsza uwaga Thilo Bode brzmiała, że absolutna dominacja niemieckiego eksportu jest odpowiedzialna za cały europejski kryzys (Bode, 2013, s. 42).

Ekonomista z Uniwersytetu Harvarda Kenneth Rogoff w swej analizie głębokiego kryzysu Unii Europejskiej uważał z kolei, że Grecja przynajmniej na kilka lat powinna opuścić strefę euro i z powrotem wprowadzić drachmę (Rogoff, 2012, s. 80). Powrót drachmy według Rogoffa umożliwiłby dewaluację narodowej greckiej waluty i przywrócenie konkurencyjności eksportu oraz branży turystycznej. Rogoff nie zgadzał się z opiniami większości europejskich polityków, że rezygnacja Grecji z euro oznaczałaby początek końca całej eurostrefy. Zgodził się natomiast z tymi, którzy twierdzili, że w przypadku tak ciężkiego kryzysu finansowego z jakim boryka się Europa nie ma prostych rozwiązań i każdy scenariusz wydarzeń jest możliwy. Przyznał też, że największym zwycięzcą strefy euro są Niemcy (Rogoff, 2012, s. 81).

Niemiecki badacz Andreas Fisahn stwierdzał, że z perspektywy europejskiej pierwsze 4 lata rządów Angeli Merkel oznaczały 4 lata kryzysu (Fisahn, 2013, s. 9). Bez względu na późniejsze interpretacje lub tylko przypadkowy charakter; okres jej rządów zbiegł się z początkiem europejskiego kryzysu. Sam Fisahn interpretował to jako rezultat neoliberalnej polityki rządu federalnego w kierunku konkurencyjnej Europy, co razem $\mathrm{z}$ autorytarnym brukselskim rządem gospodarczym przyniosło politykę na koszt i na szkodę Europy (Fisahn, 2013, s. 9). Głęboka nierównowaga gospodarcza pomiędzy poszczególnymi krajami UE umożliwiła i przyspieszyła kryzys. Fisahn uznał, że jeśli autorytarny neoliberalizm polityki gospodarczej Merkel zakończy się fiaskiem, to ewentualna alternatywa jest również niepokojąca i trudna do przewidzenia. Bezpośrednim skutkiem byłby - zdaniem niemieckiego badacza - skrajny nacjonalizm i szowinizm w poszczególnych krajach UE. Jego pierwsze sygnały i przejawy sąjuż widoczne w wielu krajach UE. Fisahn wymienił m.in.: sukcesy wyborcze partii narodowo-szowinistycznych w rodzaju Orbana na Wegrzech, przywrócenie kontroli granicznych w niektórych krajach strefy Schengen; wypowiedzenie przez Niemcy europejskiego układu o ubezpieczeniach z 1953 roku zobowiązującego do zapewnienia obywatelom innych krajów tych samych warunków pracy i płacy co własnym.

Fisahn zwrócił też uwagę, że można zapomnieć o europejskiej solidarności jeśli wszystkie kraje w istocie myślą tylko o własnych interesach (Fisahn, 2013, s. 9). Sformułował teze, że aktualny kryzys nie jest nawet w pełnym tego słowa znaczeniu głębokim kryzysem euro czy kryzysem zadłużeniowym, ale kryzysem całej europejskiej architektury gospodarczej i finansowej. Zdaniem Fisahna jedynym wyjściem z tej katastrofy jest rewizja europejskich układów. Według niemieckiego badacza Unia Europejska musi być tworzona od nowa; po zniesieniu jej czterech centralnych błędów konstrukcyjnych: 1) niedemokratycznej struktury decyzyjnej; 2) autorytarnego państwa opartego na konkurencji; 3) deregulacji rynków finansowych; 4) zachowania narodowych ekonomii.

Wymieniony przez Fisahna w punkcie czwartym błąd był co najmniej kontrowersyjny i dyskusyjny. Można się było wprawdzie zgodzić z jego tezą, że jednolita waluta 
nie funkcjonuje $w$ warunkach dalszego trwania $\mathrm{i}$ istnienia narodowych ekonomii (Fisahn, 2013, s. 12). W tym konkretnym jednak przypadku Fisahn najwyraźniej pomylił przyczyny ze skutkami; fatalne doświadczenia związane z wprowadzeniem tzw. paktu fiskalnego, czyli neoliberalnej gospodarki na obszarze całej UE przeczyły jednoznacznie tej tezie. Z głębokim kryzysem społecznym i finansowym wewnątrz UE znacznie lepiej (poza Niemcami i Francją) radziły sobie właśnie te gospodarki, które pozostały przy swojej narodowej walucie.

Ewolucja roli Niemiec w Europie i Unii Europejskiej następowała ewolucyjnie stopniowo i wyznaczały ją:

- polityka wobec Jugosławii w latach 1991-1999;

- zmiana doktryny wojskowej Bundeswehry z obrony terytorialnej na operacje out of area i przyjęcie modelu armii interwencyjnej;

- logistyczne i wywiadowcze wsparcie dla USA w okresie bezprawnej wojny przeciwko Irakowi;

- czasowe tzw. partnerstwo w przywództwie ze Stanami Zjednoczonymi;

- samodzielny wybór partnerów w stosunkach międzynarodowych;

- polityka Gerharda Schrödera i Angeli Merkel akcentująca priorytet niemieckiego interesu narodowego w Europie.

Każdy z tych etapów nowej-starej niemieckiej polityki zagranicznej wymaga choćby skrótowego omówienia. Zwłaszcza w kontekście podstawowej tezy badawczej artykułu, że europejskie przywództwo znajduje się w rękach Niemiec i że to Niemcy decydują o przyszłości Europy i Unii Europejskiej. 12 lipca 1994 roku Federalny Trybunał Konstytucyjny w Karlsruhe zdecydował, że Ustawa Zasadnicza RFN dopuszcza udział Bundeswehry w operacjach wojskowych poza obszarem sojuszu (out of area) (Hubel, May, 1995, s. 33 -42). 14 lipca tego samego roku w rocznicę Wielkiej Rewolucji Francuskiej jednostki Bundeswehry po raz pierwszy od zakończenia wojny maszerowały przez Champs-Elysees w Paryżu - w 50 lat po wyzwoleniu w 1944 roku okupowanej przez hitlerowskie Niemcy stolicy Francji. W sensie symbolicznym udział niemieckich jednostek $w$ tej paradzie bardziej niż cokolwiek innego sygnalizował zmianę wcześniejszego statusu Niemiec w Europie; już nie jako pokonany wróg i kraj odpowiedzialny za bezprzykładne zbrodnie z okresu II wojny światowej, ale jako równoprawny partner świadomy swojej sily i potęgi, pozbawiony historycznych obciążeń i kompleksów. Na reprezentacyjnej alei francuskiej stolicy zjednoczone Niemcy odnosiły swój wielki triumf. Horror Holocaustu, ludobójczej wojny przeciwko Związkowi Radzieckiemu i całej II wojny światowej nie stanowił już żadnej bariery dla międzynarodowej legitymizacji odrodzonego niemieckiego państwa narodowego.

Jednym z pierwszych polskich badaczy, który dostrzegł aktualność problemu niemieckiego w Europie był niemcoznawca Bogdan Koszel (Koszel, 1994, s. 33-42). Koszel zgodził się z poglądem wyrażonym w 1990 roku przez znanego niemieckiego historyka Michaela Stürmera, że zakończył się podział Niemiec, ale otwarta pozostała kwestia niemiecka (Koszel, 1995, s. 33). W swojej wczesnej i pionierskiej analizie Koszel zwracał uwagę na nową-starą rolę Niemiec w Europie, przywrócenie ich mocarstwowego statusu i potencjalne moźliwości prowadzenia przez nie polityki globalnej.

Polski badacz stawiał zasadnicze pytanie, czy zjednoczenie Niemiec stanowi realną groźbę dla całego kontynentu europejskiego? Zawarł już wówczas aktualne do dzisiaj 
uwagi, że w niemieckich miastach raz po raz płoną domy dla azylantów i znajdują się tam ludzie mówiący otwarcie o rewizji europejskich granic (Koszel, 1995, s. 34; Begrich, 2015, s. 9-15). Koszel trafnie też zauważyl związki pomiędzy tzw. polityką historyczną a instrumentalizowaniem historii i mniej lub bardziej jawnym dążeniem do hegemonii i ekspansji. Pisał, że celowo i rozmyślnie relatywizuje się zbrodnie hitlerowskie i eksponuje głównie te stalinowskie. Zjednoczenie Niemiec - co Koszel podkreślał - oznaczało rezygnację czterech mocarstw - ZSRR, Francji, Wielkiej Brytanii i USA z dalszej odpowiedzialności za ich losy. Tu - od razu dodajmy - rezygnacji z kontroli zapewniającej przez kilkadziesiąt lat europejski spokój i bezpieczeństwo przed Niemcami.

Koszel przyznawał, że Niemcy ponownie stały się mocarstwem i że praktycznie nie ma dla nich już żadnej autentycznej przeciwwagi na kontynencie. Równowaga sił w Europie załamała się wraz z upadkiem Związku Radzieckiego i zjednoczeniem Niemiec. Analiza Bogdana Koszela pomimo upływu czasu zachowała aktualność. Więcej - okazało się, że polski badacz zaledwie kilka lat po zjednoczeniu RFN i NRD postawił trafne hipotezy badawcze. Koszel m.in. już w 1994 roku oceniał, że Francja nie jest w stanie skutecznie konkurować z Niemcami. Rywalizację tę przegrała znacznie wcześniej, bo już w latach 60-tych (Begrich, 2015, s. 35). W cytowanym przez Koszela sondażu Prognos-Institut z 1994 roku przeprowadzonego na zlecenie gazet „Handelsblatt” i „Wall Street Journal” 50\% Francuzów było przekonanych, że zjednoczone Niemcy będą dążyć do hegemonii w Europie.

Koszel przypominał uwagi niemieckich konserwatystów takich jak historyk Arnulf Baring i biograf Hitlera Joachim Fest, którzy wprost stwierdzali, że Niemcy wykorzystają swoje otoczenie do spełnienia historycznej misji na Wschodzie i że właśnie tam powinno się znaleźć ujście dla ich życiowej aktywności (Begrich, 2015, s. 38). Cytowani przez polskiego badacza francuscy i amerykańscy politolodzy uważali z kolei, że w przyszłości energia olbrzymiego potencjału niemieckiego musi znaleźć swe zewnętrzne ujście w postaci ekonomicznej i politycznej ekspansji w Europie Środkowo-Wschodniej i Wschodniej (Begrich, 2015, s. 39).

Bogdan Koszel zgodził się też z niektórymi badaczami amerykańskimi, że Europa Środkowa i Południowo-Wschodnia to naturalne zaplecze surowcowe Niemiec. Wymieniony przez Koszela amerykański publicysta Stephen Kinver na łamach „The New York Times" z 17 grudnia 1991 roku obrazowo odniósł się do równowagi sił w Europie po zjednoczeniu Niemiec i napisał, że Związek Radziecki przeminął, a Niemcy powróciły (Begrich, 2015, s. 39). W swojej analizie Koszel zawarł też uwagi Williama Horsley, korespondenta BBC w Bonn, który tylko w latach 1990-1992 doszukał się 7 kardynalnych grzechów niemieckiej polityki zagranicznej. Horsley wymienił m.in. kunktatorstwo Helmuta Kohla w kwestii ostatecznego uznania polskiej granicy zachodniej, wysoką stopę procentową utrzymywaną przez Bundesbank uniemożliwiającą ożywienie zachodnioeuropejskiej gospodarki czy widoczne niemieckie próby zdominowania organów Wspólnoty Europejskiej (Begrich, 2015, s. 40).

Trudno też nie zgodzić się z Bogdanem Koszelem, że apogeum niechęci państw zachodnich do niemieckiej polityki zagranicznej zostało osiagnięte podczas wojny domowej w Jugosławii. Wbrew radom USA, sekretarza generalnego ONZ, większości państw wspólnoty europejskiej Niemcy rozmyślnie i przedwcześnie uznały niepod- 
ległość Słowenii i Chorwacji. Przyczyniły się wówczas do rozpętania bośniackiej tragedii. Krok ten był powszechnie interpretowany jako pierwsza próba samodzielnego działania zjednoczonych Niemiec na arenie międzynarodowej (Begrich, 2015, s. 41).

Koszel pisał, że w pierwszej połowie 1992 roku w instytucjach Wspólnoty Europejskiej najczęściej powtarzane hasło brzmiało „stop the Germans now! - zatrzymajcie Niemców teraz". Można również powtórzyć za znanym niemcoznawcą że Niemcy jak dotąd nie radzą sobie z jasnym zdefiniowaniem celów w polityce zewnętrznej i jego dalszą uwagą, że dotychczasowe priorytety, zasady moralne i linie postępowania Niemiec zostały zachwiane. Analiza Bogdana Koszela - co warto jeszcze raz podkreślić - była pionierska i w kontekście późniejszych wydarzeń niemal prorocza. Koszel jako jeden z pierwszych polskich badaczy dostrzegł otwarty charakter problemu niemieckiego.

W maju 1989 roku prezydent USA George Bush senior określił starą RFN (jeszcze przed zjednoczeniem z NRD) jako partnera w przywództwie (partner in leadership) Stanów Zjednoczonych (Hubel, May, 1995, s. 67). Bill Clinton poszedł jeszcze dalej od swego poprzednika w podkreślaniu szczególnej roli Niemiec w Europie i wagi stosunków amerykańsko-niemieckich. W lipcu 1994 roku Clinton mówił o wyjątkowym i unikalnym partnerstwie pomiędzy Ameryką a Niemcami (Hubel, May, 1995, s. 67). W tym samym roku w 5 lat po upadku muru berlińskiego w przemówieniu pod Bramą Brandenburską Clinton w bezprecedensowy sposób oświadczył, że Ameryka stoi po waszej (Niemiec) stronie, teraz i na zawsze (Hubel, May, 1995, s. 69). Badacze niemieccy za symboliczne i znamienne uznali, że decyzja Federalnego Trybunału Konstytucyjnego o zgodności z Ustawą Zasadniczą operacji wojskowych Bundeswehry poza obszarem NATO została ogłoszona dokładnie w dniu, w którym Clinton wygłaszał swoje przemówienie przed Bramą Brandenburską (Hubel, May, 1995, s. 69).

Jednak największe obawy i kontrowersje wśród obserwatorów zagranicznych budziła zmiana doktryny wojskowej Bundeswehry (Hubel, May, 1995, s. 69). Znany niemiecki badacz Alexander Neu przypomniał słowa federalnego ministra obrony Petera Strucka z 2004 roku, że bezpieczeństwo Niemiec będzie bronione również pod Hindukuszem (Neu, 2006, s. 788-791). Z kolei tytuł analizy Alexandra Neu „obrona bez granic" przemawiał do wyobraźni i dawał do myślenia tym wszystkim, którzy zajmowali się tą nową i zmienioną rolą Niemiec w Europie i świecie. Niemcy odchodzily od dotychczasowych założeń swojej doktryny wojskowej i przestawiały się na typowe zadania armii interwencyjnej. W każdym rejonie świata. Wszędzie tam gdzie przy użyciu sił zbrojnych miały być bronione niemieckie interesy narodowe. Federalne Ministerstwo Obrony wprost stwierdzało, że zmienione wyzwania w zakresie bezpieczeństwa wymagają nowej interpretacji Karty Narodów Zjednoczonych i dopuszczają użycie prewencyjnych środków wojskowych (Neu, 2006, s. 789).

Neu zwracał uwage, że w istocie to pożegnanie z zasadami obrony terytorialnej oznaczało odrzucenie prawa ONZ, na podstawie którego (art. 24, 39, 41, 42 Karty ONZ) tylko Rada Bezpieczeństwa posiada monopol na podjęcie decyzji o użyciu siły (Neu, 2006, s. 789). Neu stwierdzał, że dla zachowania pozorów legalizmu wskazywano na dynamiczny i zmienny charakter prawa międzynarodowego. Niemiecki badacz trafnie zauważał też, że przesunięcie punktu ciężkości z obrony terytorialnej na globalną obronę niemieckich interesów stanowiło całkowity zwrot w polityce obronnej RFN po 1990 roku (Neu, 2006, s. 789). Jego zdaniem w stosunkach międzynarodo- 
wych oznaczało to wyraźny krok wstecz i regres w duchu XIX i wczesnego XX stulecia. W tym znaczeniu i tym sensie zdaniem Neu prawo międzynarodowe miało uwzględniać możliwość prowadzenia wojny zaczepnej pod pretekstem zmieniających się i uniwersalnych ,nowoczesnych” warunków bezpieczeństwa (Neu, 2006, s. 789). W takim też kontekście Neu definiował pojęcie obrony: jest to wojskowa reakcja na wspólny atak innego państwa (państw) na własne terytorium. Po 11 września 2011 roku również w niemieckiej doktrynie wojskowej zakorzeniło się pojęcie wojny prewencyjnej i uprzedzającej (Neu, 2006, s. 790). Jako drastyczne przykłady tej nowej-starej doktryny Neu wymienił tzw. koalicje „,chętnych” i agresywne wojny zarówno te prewencyjne, jak i uprzedzające prowadzone przeciwko Federacyjnej Republice Jugosławii i Irakowi. Państwa NATO i UE reanimowały średniowieczną naukę o, ,wojnie sprawiedliwej" (Tönnies, 2003, s. 778).

W taki sposób - wedhug Neu - każda wojna zaczepna, której prawdziwym celem było zdobycie nowych rynków zbytu, dostęp do surowców i podbój mogła być legitymizowana jako prewencyjna samoobrona (Neu, 2006, s. 791). Z perspektywy uwag Alexandra Neu warto dokładniej zająć się wystapieniem federalnego ministra obrony Petera Strucka z 13 stycznia 2004 roku (Einsatzgebiet, 2004, s. 376). Redakcja „Blätter..." z krótkim komentarzem opublikowała pełny tekst wystąpienia Strucka. Przyznała, że po raz pierwszy od zakończenia II wojny światowej 23 marca 1999 roku niemieckie siły zbrojne wzięły aktywny udział $w$ działaniach bojowych przeciwko $\mathrm{Fe}$ deracyjnej Republice Jugosławii (Einsatzgebiet, 2004, s. 375). W komentarzu trafnie zauważono, że udział Bundeswehry w bombardowaniach NATO oznaczał ostateczne pożegnanie niemieckich sił zbrojnych z zadaniami armii obronnej. Ówczesne wystąpienie w Bundestagu Strucka było zresztą jednoznaczne i nie pozostawiało żadnych watpliwości czy ewentualnego pola do dowolnych interpretacji: minister zupełnie otwarcie oświadczał, że obszarem działania Bundeswehry jest cały świat (Einsatzgebiet, 2004, s. 376). Struck nie ukrywał, że celem rządu federalnego jest stworzenie armii interwencyjnej zdolnej do prowadzenia działań bojowych na całym świecie. We wszystkich - jak to elegancko ują - regionach kryzysowych.

Uwaga badaczy zajmujących się tą nową-starą niemiecką polityką zagraniczną ze zrozumiałych względów koncentrowała się przede wszystkim na polityce RFN wobec Jugosławii w latach 1991-1999 (Waldenberg, 2015; Reszczyński, 2010, s. 32-34; Dahn, 2014, s. 67). Jednostronne uznanie przez Niemcy niepodległości (secesji) dwóch jugosłowiańskich republik związkowych Chorwacji i Słowenii w dniu 23 grudnia 1991 roku rozpoczęło krwawą wojnę domową na obszarze tego kraju zakończoną rozbiciem i upadkiem tego kraju (Młynarski, 2006, s. 193). Ówczesny niemiecki minister spraw zagranicznych Klaus Kinkel już 24 maja 1992 roku z rzadko spotykaną w dyplomacji szczerością oświadczył, że musimy (Niemcy) rzucić Serbów na kolana (Elsässer, 2003, s. 134). Jürgen Elsässer zajmujący się analizą polityki zagranicznej tego kraju pisał wprost o fatalnej roli BND w rozbiciu Jugosławii (Elsässer, 2003, s. 137). Cytował m.in. uwagi byłego szefa jugosłowiańskich służb specjalnych Duhacka z okresu rządów Josipa Broz Tity; według Duhacka już na przełomie 1993 i 1994 roku BND zażądała dokonania czystek w chorwackich służbach specjalnych. Wszyscy oficerowie wywodzący się z partyzanckich i komunistycznych tradycji Tity musieli natychmiast odejść. Wspólnym mianownikiem tego egzotycznego „sojuszu” pomiędzy chorwacki- 
mi służbami, a BND stał się chorwacki nacjonalizm i wrogość wobec Jugosławii. Na tym polu spotkały się siły, które tak zaciekle zwalczały się w okresie II wojny światowej: narodowi komuniści i faszystowscy ustasze. BND zażądało jednak oczyszczenia chorwackich służb specjalnych tylko z tych pierwszych (Elsässer, 2003, s. 137).

Okres sprawowania urzędu kanclerskiego przez Gerharda Schrödera rozpoczął ere akcentowania niemieckiego interesu narodowego w Europie (Młynarski, 2006, s. 195-210). Następowało odchodzenie od polityki Konrada Adenauera. Zjednoczenie Niemiec przywróciło niemieckie państwo narodowe i automatycznie unieważniało politykę Adenauera świadomie odsuwającą w czasie przywrócenie takiego państwa. Niemcy powracały do polityki Bismarcka i Stresemanna w ramach Unii Europejskiej jako wiodąca siła Europy i największe regionalne mocarstwo. Opiniotwórczy niemiecki „Die Zeit” już w 2001 roku sygnalizował tą zmianę (Wernicke, 2001, s. 1). Analityk tygodnika Christian Wernicke pisał wprost, że polityka europejska w okresie rządów Gerharda Schrödera stała się bardziej narodowa niż kiedykolwiek. Cytowany przez Wernicke i niewymieniony $\mathrm{z}$ nazwiska wysokiej rangi doradca UE w rządzie portugalskim stwierdzał, że Niemcy chcą Europy jako szkieletu, jako kości bez mięsa (Wernicke, 2001, s. 1). Na krótko przed objęciem urzędu kanclerza Schröder zupełnie otwarcie oświadczył, że jeżeli będzie to konieczne, niemieckie interesy narodowe będą w brutalny sposób chronione i bronione. Wernicke pisał też, że Bruksela stała się przedłużonym narzędziem berlińskiej polityki zagranicznej i zakładnikiem niemieckiej polityki wewnętrznej. W gruncie rzeczy - zdaniem Wernicke - chodziło o to, by cała Europa podporządkowała się niemieckim regułom gry i celom jej polityki zagranicznej. Niemiecki analityk podkreślił też widoczną i drastyczną ewolucję roli Niemiec w Europie; od politycznego karła z czasów starej RFN do ekonomicznego i politycznego olbrzyma, który decyduje o losie całego kontynentu (Wernicke, 2001, s. 1).

Lata 1991-2014 wyznaczały kolejne i nastepujące po sobie kompromitacje UE i Niemiec, podważające ich wiarygodność. Oficjalnie potępiano wszelkie formy nacjonalizmu i szowinizmu u siebie i równocześnie wspierano ruchy separatystyczne i odśrodkowe w innych krajach (Zielonka, 2014). Tragedia Jugosławii była klinicznym przykładem, że oficjalnie głoszone i propagowane zasady miały charakter wyłącznie przejściowy i instrumentalny. Pożegnano się z nimi, gdy tylko było to zgodne z niemieckim interesem narodowym. Po roku 1990 w skali całej Europy można było dostrzec groźną i niepokojącą tendencję; niemieckiej integracji (zjednoczenie RFN i NRD) towarzyszyła europejska dezintegracja, by wymienić w tym miejscu tylko rozpad ZSRR, rozbicie Jugosławii, sztuczne powstawanie na Bałkanach nowych i małych krajów, podział Czechosłowacji na dwa odrębne państwa i błyskawiczne uznanie przez UE niepodległości Kosowa. Wnioski nasuwały się same.

Znana niemiecka pisarka i publicystka Daniela Dahn pisała, że wojna NATO przeciwko Jugosławii była całkowicie bezprawną wojną prowadzoną bez mandatu ONZ; z punktu widzenia prawa międzynarodowego stanowiła agresywną wojnę skierowaną przeciwko suwerennemu państwu (Dahn, 2014, s. 60). Historia bezprawnej wojny NATO przeciwko Jugosławii przekracza ramy jednego artykułu i nie jest właściwym przedmiotem jego analizy; w tym miejscu autor tekstu jedynie sygnalizuje problem świadomej dezintegracji przez UE i USA innych państw i katastrofalnych skutków takiej polityki. Scenariusz jugosłowiański został przez UE i NATO powtórzony na Ukra- 
inie. Tu również wykorzystano siły odśrodkowe i skrajnie nacjonalistyczne, by pod pretekstem obrony wolności i demokracji obalić legalne i konstytucyjne władze Ukrainy i doprowadzić do faktycznej dezintegracji tego kraju. Wybitny polski filozof Bronisław Łagowski trafnie stwierdzał, że nacjonalizm jest zły, gdy sprzeciwia się Unii Europejskiej, ale jest wyśmienity, gdy budzi nienawiść do Rosji (Łagowski, 2014, s. 21). Łagowski pisał, że w Odessie zwolennicy Europy spalili żywcem 40 zwolenników Rosji. Ironizował, że Rosjanie są tym wprawdzie dogłębnie wstrząśnięci, ale Europejczycy i Amerykanie już nie. Starają się tamte wydarzenia przemilczeć, opis złagodzić, a dla sprawców znaleźć okoliczności łagodzące (Łagowski, 2014, s. 21).

W analizie zatytułowanej Kryzys krymski $i$ wiarołomstwo Zachodu niemiecki badacz Reinhard Mutz zauważał, że po rozpadzie Związku Radzieckiego w 1991 roku kraj ten zmniejszył się z 270 do 150 milionów mieszkańców (Mutz, 2014, s. 7). Jedna szósta ludności, 25 milionów Rosjan znalazło się poza nowymi granicami swojego kraju. Rosja straciła - o czym Mutz stale przypominał - ponad 100 milionów obywateli i jeden milion kilometrów kwadratowych swego strategicznego terytorium. Według Mutza pomimo tych oczywistych faktów, Zachód (USA i UE) w dalszym ciagu konserwował obraz wroga i nigdy nie traktował Rosji jak równoprawnego partnera. W praktyce odrzucił koncepcję budowy nowej europejskiej architektury bezpieczeństwa z udziałem Rosji.

Niemiecki badacz zwrócił też uwage, że podstawowym warunkiem radzieckiej zgody na zjednoczenie Niemiec w 1990 roku i ich członkostwa w NATO była zachodnia obietnica złożona Michaiłowi Gorbaczowowi przez ówczesnego amerykańskiego sekretarza stanu Jamesa Bakera, że NATO nie rozszerzy swego terytorium ani o centymetr w kierunku Wschodu (Mutz, 1997, s. 86-92). Od tamtego okresu zachodni sojusz wojskowy przesunął się o 1200 kilometrów na Wschód, od granicy niemieckiej po granicę z Rosją (Mayr, 2008, s. 140). W chwili zjednoczenia Niemiec NATO liczyło 16 członków. Po kolejnych etapach rozszerzenia z 1999, 2004 i 2008 roku do NATO należy 28 krajów, w tym 6 byłych radzieckich sojuszników i 3 byłe radzieckie republiki. Mutz stwierdzał, że pierwszy etap dryfu NATO na Wschód prowadził od Elby do Odry. Polskie członkostwo osiągnęło już linię rzeki Bug. Zdaniem Mutza wydarzenia ukraińskie zapowiadały 3 etap ekspansji NATO, czyli osiagnięcie przez Zachód linii Dniepru jako nowej strefy wpływów USA i UE.

Kwestia niemieckiego przywództwa w Europie nie jest już kwestionowana przez żadnego poważnego badacza. Różnice dotycząjedynie interpretacji jak owo przywództwo zostanie wykorzystane: w interesie czy przeciwko Europie. Naiwne i nieprawdziwe byłoby jednak założenie, że problem niemiecki w Europie już nie istnieje lub, że został zamknięty wraz ze zjednoczeniem RFN i NRD. Na podstawie powyższych przesłanek wyciągnąć można następujące wnioski: 1) zjednoczenie Niemiec załamało równowagę sił w Europie; 2) rozszerzenie NATO i UE na Wschód przesunęło strefę wojskowych i politycznych wpływów USA po linię rzeki Bug; 3) Niemcy umocniły pozycję europejskiego mocarstwa i hegemona; 4) polityka zagraniczna Angeli Merkel stanowi kontynuację polityki zagranicznej Gerharda Schrödera; politykę przeniesienia punktu ciężkości niemieckiej polityki zagranicznej z polityki europejskiej na politykę priorytetu narodowych interesów Niemiec; 5) kwestia niemiecka zachowała swój otwarty charakter. 


\section{Bibliografia}

Ash T. G. (1993), Im Namen Europas. Deutschland und der geteilte Kontinent, München.

Bartosz J. (2013), Co z ta hegemoniq Niemiec?, „Przeglad”, nr 46 z 12-17.11.2013.

Begrich D. (2015), Tröglitz: Der pragmatische Rassismus, „Blätter für deutsche und inernationale Politik", nr 5.

Bode T. (2013), Europa und die mutlose Linke, „Blätter für deutsche und inernationale Politik”, nr 4.

Dahn D. (2014), „Kosowo stato sie praktycznie protektoratem NATO, „Blätter für deutsche und inernationale Politik", nr 11.

Dahn D. (2014), Frieden muss gestrftet werden. Exempel Kosovokrieg oder: das Völkerrecht als Gegner, „Blätter für deutsche und inernationale Politik”, nr 11.

Einsatzgebiet für die Bundeswehr ist die ganze Welt. Rede von Bundesverteidigungsminister Peter Struck zur Konzeption und Weiterentwicklung der Bundeswehr vom 13. Januar 2004 (Wortlaut) (2004), „Blätter für deutsche und inernationale Politik”, nr 3.

Elsässer J. (2003), Der Deutsche Sonderweg. Historische Last und politische Herausforderung. München.

Fisahn A. (2013), Vier Jahre Merkel, vier Jahre Eurokrise, „Blätter für deutsche und inernationale Politik", nr 9.

Fischer J., Enderlein H., Calliess Ch. (2011), Europa und die neue Deutsche Frage.Ein Gespräch mit Jürgen Habermas, „Blätter für deutsche und inernationale Politik”, nr 5.

Friedman G. (2012), Nastepna dekada. Gdzie byliśmy i dokad zmierzamy, Kraków.

Hubel H., May B. (1995), Ein „normales” Deutschland? Die souveräne Bundesrepublik in der ausländischen Wahrnehmung, Bonn.

Kaufmann S. (2012), Europa unter deutscher Fuchtel, „Blätter für deutsche und inernationale Politik", nr 1 .

Koszel B. (1994), Niemcy na rozdrożu?, „Europa”, nr 1(6), Poznań.

Kraszewski J. (1997), Jak Baker NATO na Labie zatrzymat, „Dzis'”, nr 8.

Łagowski B. (2014), Skomplikowane i proste, „Przegląd”, $\mathrm{nr} 22$ z 26.5.-1.06.2014.

Mayr W. (2008), Ein Riss im Bollwerk, „Der Spiegel”, nr 49.

Mlynarski A. (2006), Niemcy jako polityczny problem Europy 1949-2002. Kontynuacja i zmiana polityki zagranicznej Konrada Adenauera, Kielce.

Mutz R. (2014), Die Krimkrise und der Wortbruch des Westens, „Blätter für deutsche und inernationale Politik", $\mathrm{nr} 4$.

Neu A. (2006), Verteidigung grenzenlos, „Blätter für deutsche und inernationale Politik”, nr 7.

Pradetto A. (1990), Zusammenbruch des „,Real-Sozialismus”, deutsche Einheit und europäische Integration, Europäische Rundschau, „Herbst”, nr 4.

Reszczyński Ł. (2010), Europejskie domino. Stanowisko Międzynarodowego Trybunalu Sprawiedliwości w sprawie Kosowa wzmacnia separatystów, „Przegląd”, $\mathrm{nr} 32$ z 15.8.2010.

Rogoff K. (2012), Deutschland ist Gewinner, „Der Spiegel”, nr 8.

Schaff A. (1999), Próba podsumowania, Warszawa.

Tönnies S. (2003), Ist das Völkerrecht noch zu retten?, „Blätter für deutsche und inernationale Politik", nr 7.

Waldenberg M. (2005), Rozbicie Jugostawii. Jugostowiańskie lustro międzynarodowej polityki. Warszawa. 
Wernicke Ch. (2001), Die teutonische Agenda, „Die Zeit”, nr 50.

Zielonka J. (2014), Koniec Unii Europejskiej?, PISM, Warszawa.

\section{Streszczenie}

Artykuł jest próbą analizy europejskiego przywództwa i roli zjednoczonych Niemiec w Unii Europejskiej. Autor stawia 5 podstawowych tez: 1) zjednoczenie Niemiec załamało równowagę sił w Europie; 2) rozszerzenie NATO i UE na Wschód przesunęło strefę wojskowych i politycznych wpływów USA po linię rzeki Bug; 3) Niemcy umocniły pozycję europejskiego mocarstwa i hegemona; 4) polityka zagraniczna Angeli Merkel stanowi kontynuację polityki zagranicznej Gerharda Schrödera; politykę przeniesienia punktu ciężkości niemieckiej polityki zagranicznej z polityki europejskiej na politykę priorytetu narodowych interesów Niemiec; 5) kwestia niemiecka zachowała swój otwarty charakter.

Słowa kluczowe: przywództwo, Niemcy, Unia Europejska, hegemonia, polityka, doktryna

\section{European leadership. Germany in the European Union}

\section{Summary}

This paper is an attempt to analyse European leadership and the role played by a reunited Germany in the European Union. The author proposes five fundamental theses: 1) the reunification of Germany ruined the balance of power in Europe; 2) the Eastern enlargement of NATO and the EU has moved the zone of political and military influence of the USA to the line of the Bug river; 3) the Germans have confirmed their position as a European power; 4) the foreign policy of Angela Merkel is a continuation of Gerhard Schroder's policy, meaning a transfer of the focus from European policy to prioritising German national interests; 5) the German issue has remained open.

Key words: leadership Germany, European Union, hegemony, policy, doctrine 
